\title{
KELIMPAHAN DAN KEANEKARAGAMAN ARTHROPODA PERMUKAAN TANAH PADA BEBERAPA LOKASI PERTANAMAN UBI KAYU (Manihot esculenta Crantz) DI LAMPUNG
}

\section{ABUNDANCE AND DIVERSITY OF SOIL SURFACE ARTHROPODS AT SEVERAL LOCATIONS OF CASSAVA (Manihot esculenta Crantz) FIELDS IN LAMPUNG}

\author{
Christ Arissandhi Pandiangan*, F.X Susilo, Agus Muhammad Hariri, I Gede Swibawa \\ Jurusan Agroteknologi, Fakultas Pertanian, Universitas Lampung \\ J1 Sumantri Brojonegoro 1, Bandar Lampung 35145, Indonesia \\ *Email: christpandiangn@gmail.com
}

\begin{abstract}
The study aims to understand the abundance and diversity of soil surface arthropods at several locations of the cassava fields in Lampung Province. The first and second locations were in Tanjung Sari Village, South Lampung, while the third and fourth locationswere in Bumi Aji Village, Central Lampung. The fifth and the sixth locationswere located in Pekalongan Village (East Lampung) in Sukaraja Nuban (East Lampung). Arthropod samples were taken by pitfall trap (diameter $13 \mathrm{~cm}$, height $20 \mathrm{~cm}$ ) which were done five times at sixth different locations of cassava fields. Arthropods were collected invials with 70\%alcohol, then were identified inLaboratory of Plant Pests Faculty of Agriculture, Lampung University. The results show that arthropods from soil surface, was varied, comprisedof six order of arthropods. Among them, Collembola and ants showed the highest abundance prominance value (PV). Shannon's index of the soil surface arthropods ranged between 0,62 to 1,17 and Simpson index ranged between 0,3-0,5.
\end{abstract}

Keywords: Abudance, cassava field, diversity, soil surface arthropods.

\begin{abstract}
ABSTRAK
Penelitian ini bertujuan untuk mengetahui kelimpahan dan keanekaragaman Arthropoda permukaan tanah di beberapa lokasi pertanaman ubikayu di Provinsi Lampung. Lokasi 1 dan 2 terletak di desa Tanjung Sari, Lampung Selatan, lokasi 3 dan 4 terletak di desa Bumi Aji, Lampung Tengah, lokasi 5 di desa Pekalongan, Lampung Timur dan lokasi 6 di desa Sukaraja Nuban, Lampung Timur. Pengambilan sampel Arthropoda menggunakan pitfall trap (diameter $13 \mathrm{~cm}$, tinggi $20 \mathrm{~cm}$ ) dilakukan lima kali (lima minggu) pada enam lokasi pertanaman ubikayu. Arthropoda hasil tangkapan dikoleksi dalam botol vial dengan alkohol $70 \%$, selanjutnya diidentifikasi di Laboratorium Ilmu Hama Tumbuhan Fakultas Pertanian Universitas Lampung. Hasil penelitian menunjukkan bahwa kelimpahan total arthropoda permukaan tanah dari 6 lokasi adalah bervariasi, terdiri atas tujuh kelompok Arthropoda. Di antara enamordo arthropoda yang ditemukan, terdapat dua kelompok yang memiliki kelimpahan dan nilai penting $(\mathrm{PV})$ tertinggi, yaitu Collembola dan semut. Nilai indeks Shannon arthropoda pada pertanaman ubi kayu pada kisaran antara 0,6 sampai 1,17 dan indeks Simpson antara 0,3-0,5.
\end{abstract}

Kata kunci : Arthropoda permukaan tanah, keanekaragaman, kelimpahan, pertanaman ubi kayu. 


\section{PENDAHULUAN}

Di Indonesia, ubi kayuditanam hampir di seluruh wilayah. Ubi kayu menjadi sumber karbohidrat utama setelah beras dan jagung. Tiga provinsi penghasil ubi kayu terbesar di Indonesia ialah Lampung, Jawa Timur, dan Jawa Tengah (BPS, 2015). Total produksi ubi kayu di Provinsi Lampung pada tahun2015mencapai 279.226ton dengan luas panen sebesar 314.607 ha. DiJawa Timur, total produksi ubi kayu adalah146.787 ton dengan luas panen 176.102 ha. Jawa Tengah memproduksi ubi kayu 150.874 ton dengan luas panen 163.330 ha.

Permasalahan umum yang dihadapi petani ubi kayu adalah produktivitas dan pendapatan yang rendah. , Rendahnya produktivitas ubi kayu disebabkan oleh belum diterapkannya teknologi budidaya ubikayu dengan benar. Salah satu teknik budidayaubi kayu yaitu pemupukan. Pupuk yang digunakan untuk ubikayu dapat berupa pupuk anorganik maupun pupuk organik (Arief \& Asnawi, 2008).

Arthropoda permukaan tanah berperan dalam proses dekomposisi material organik tanah. Oleh karena itu, arthropoda permukaan tanah menentukan siklus material tanah. Proses perombakan material organik di dalam tanah dapat berjalan lebihcepat karena bantuan arthropoda permukaan tanah. Arthropoda permukaan tanah yangberperan dalam proses dekomposisi diantaranya ordo Collembola serta Hymenoptera. Oleh karena itu kedua kelompok arthropoda permukaan tanah ini dapat digunakan sebagai indikator kesehatan tanah (Ruslan, 2009).

Perombakan material organik tanah menghasilkan unsur hara bagi tanaman. Di dalam tanah, ketersediaan unsur hara bagi tanaman tergantung dari interaksi antara tanaman dengan, organisme tanah (Bonkowski et al., 2000). Organisme tanah bermanfaat dalam dekomposisi, siklus hara, menjaga struktur tanah, maupun menjaga keseimbangan organisme tanah, termasuk hama tanaman (Moore\& Walter, 1988). Dengan demikian keberadaan arthropoda permukaan tanah pada lahan pertanaman ubi kayu sangat penting.

Keberadaan arthropoda tanah pada suatu agroeksosistem mempengaruhi stabililitasnya. Tingkat stabilitas suatu ekosistem pertanian ditentukan oleh interaksi antar komponen-komponen komunitas, antara lain organisme herbivora dan organisme karnivora. Pada suatu agroekosistem komunitas arthropoda meliputi banyak jenis dan masing-masing jenis memiliki sifat populasi yang khas.

\section{Kondisi biofisik pertanaman suatu} agroekosistem mempengaruhi komunitas arthropoda permukaan tanah. Pertanaman ubi kayu di Lampung menyebar di berbagai lokasi yang memiliki kondisi biofisik yang beragam. Oleh karena itu, maka komunitas artropda permukaan tanah yang berbada di dalamnya dapat berbeda antar lokasi pertanaman ubi kayu di Lampung. Namun demikian, belum tersedia cukup informasi mengenai hal ini. Penelitian ini bertujuan untuk mempelajari keragaman arthropoda permukaan pada bebrapa lokasi pertanaman ubi kayu di Lampung.

\section{BAHAN DAN METODE}

Tempat dan Waktu Penelitian

Penelitian ini dilakukan di enam lokasi pertanaman ubi kayu di daerah Lampung, yaitu di Desa 
Tanjung Sari 1, Desa Tanjung Sari 2 (Lampung Selatan), di Desa Bumi Aji 1, Desa Bumi Aji 2 (Lampung Tengah), di Desa Pekalongan, dan di Desa Sukaraja Nuban (Lampung Timur) yang karakteristik lokasinya disajikan pada tabel 1.Sampel arthropoda permukaan tanah yang diperoleh dari enam lokasi tersebut diidentifikasi di Laboratorium Ilmu Hama Tumbuhan, Fakultas Pertanian, Universitas Lampung. Penelitian ini dilakukan bulan Agustus 2016 sampai Oktober 2017.

\section{Pengambilan Sampel Arthropoda}

Pengambilan sampel arthropoda dilakukan di enam lokasi yaitu Desa Tanjung Sari 1, Tanjung Sari 2, Bumi Aji 1, Bumi Aji 2, Pekalongan, Dan Sukaraja Nuban (Tabel 1). Sebelum dilakukan pengambilan sampel, setiap lahan pertanaman ubi kayu yang diamati terlebih dulu diukur luasnya dengan metode penghitungan langkah kaki dan baris tanaman. Penghitungan langkah kaki dilakukan secara vertikal, sedangkan penghitungan baris tanaman dilakukan secara horizontal. Selanjutnya, ditentukan baris tananam ubi kayu paling tengah, dan garis tengah bagian lahan yang dihitung metode langkah kaki, sehingga didapat titik utama pengambilan sampel. Titik utama ini adalah titik perpotongan garis pada baris tanaman paling tengah dengan garis paling tengah dari penghitungan dengan langkah kaki (Gambar 1, Susilo \& Swibawa, 2016; komunikasi pribadi). Dari titik utama ditentukan lagi titik pengambilan sampel 2, 3, 4 dan lima yang masing-masing berposisi pada kedua garis diagonal lahan. Pada kelima titik sampel ini dipasang perangkap pitfall (Gambar 2).

Pitfall terbuat dari ember plastik berdiameter $13 \mathrm{~cm}$ dan tinggi 20 cmyang diisi larutan detergen 1\% sebanyak $100 \mathrm{ml}$. Penggunaan detergen berfungsi untuk menurunkan tegangan permukaan air sehingga arthropoda yang terperangkap tenggelam. Pitfall dipasang selama 24 jam, arthropda yang tertangkap

Tabel 1. Karakteristik lokasi pertanaman ubi kayu di tiga Kabupaten, Provinsi Lampung

\begin{tabular}{|c|c|c|c|}
\hline Kabupaten & Kecamatan/Desa & Pemilik & Karakteristik Lokasi \\
\hline \multirow{2}{*}{$\begin{array}{l}\text { Lampung } \\
\text { Selatan }\end{array}$} & \multirow[t]{2}{*}{ Natar/ Tanjung Sari } & Sahrul & $\begin{array}{l}\text { Posisi geografis Lokasi 5¹6’49,5912"' LS; } \\
105^{\circ} 12 \text { '152.8912”BT. Luas } 3.241 \mathrm{~m}^{2} \text {. Tanaman ubi kayu } \\
\text { berumur } 7 \text { bulan, klon yang ditanam UJ3 dengan jumlah } \\
\text { sebanyak } 5832 \text { tanaman. }\end{array}$ \\
\hline & & Mahyo & $\begin{array}{l}\text { Posisi geografis lokasi } 5^{\circ} 17^{\prime} 43.368^{\prime \prime} \mathrm{LS} ; 105^{\circ} 12^{\prime} 43.11^{\prime \prime} \mathrm{BT} \text {. } \\
\text { Luas } 7.697 \mathrm{~m}^{2} \text {. Tanaman ubi kayu berumur } 4 \text { bulan, klon } \\
\text { UJ3 dengan jumlah sebanyak } 11076 \text { tanaman. }\end{array}$ \\
\hline \multirow{2}{*}{$\begin{array}{l}\text { Lampung } \\
\text { Tengah }\end{array}$} & \multirow{2}{*}{ Anak Tuha/ Bumi Aji } & Subadi & $\begin{array}{l}\text { Posisi geografis lokasi } 4^{\circ} 57^{\prime} 18.9468^{\prime \prime} \text { LS; } 105^{\circ} 1^{\prime} 15.2292^{\prime \prime} \\
\text { BT. Luas } 8.732 \mathrm{~m}^{2} \text {. Tanaman ubi kayu berumur } 5 \text { bulan, } \\
\text { klon UJ3 dengan jumlah sebanyak } 13176 \text { tanaman. }\end{array}$ \\
\hline & & Tarom & $\begin{array}{l}\text { Posisi geografis lokasi } 4^{\circ} 57^{\prime} 35.19722^{\prime} \mathrm{LS} ; 105^{\circ} 0{ }^{\prime} 57.456^{\prime \prime B T} \text {. } \\
\text { Luas } 12.385 \mathrm{~m}^{2} \text {. Tanaman ubi kayu berumur } 7 \text { bulan, klon } \\
\text { UJ3 dengan jumlah sebanyak } 19110 \text { tanaman. }\end{array}$ \\
\hline \multirow{2}{*}{$\begin{array}{l}\text { Lampung } \\
\text { Timur }\end{array}$} & Pekalongan & Darwis & $\begin{array}{l}\text { Posisi geografis lokasi 504'84.599'LS; } 105^{\circ} 4^{\prime} 16.8784 \text { 'BT. } \\
\text { Luas } 14.582 \mathrm{~m}^{2} \text {. Tanaman ubi kayu berumur } 12 \text { bulan, klon } \\
\text { UJ3 dengan jumlah sebanyak } 21733 \text { tanaman. }\end{array}$ \\
\hline & $\begin{array}{l}\text { Batanghari/ Sukaraja } \\
\text { Nuban }\end{array}$ & Bibit & $\begin{array}{l}\text { Posisi geografis lokasi 5'1'36.4008'LS; } 105^{\circ} 24 \text { '20.8944'BT. } \\
\text { Luas } 4.873 \mathrm{~m}^{2} \text {. Tanaman ubi kayu berumur } 6 \text { bulan, klon } \\
\text { UJ5 dengan jumlah sebanyak } 6916 \text { tanaman. }\end{array}$ \\
\hline
\end{tabular}




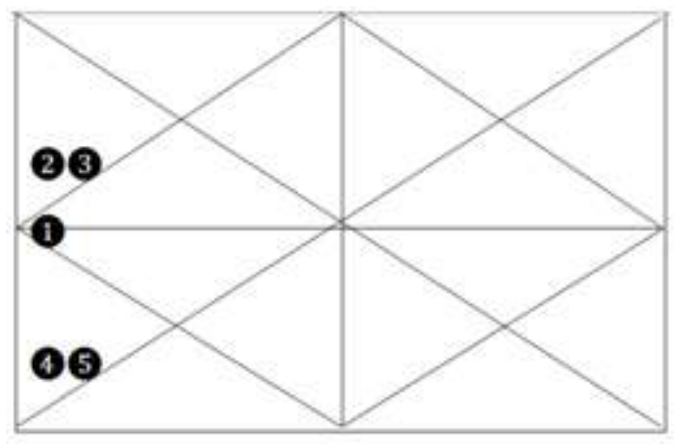

Gambar 1. Posisi pemasangan pitfall trap Keterangan:

$1=$ perangkap 1
$2=$ perangkap 2
3 $=$ perangkap 3

(4) $=$ perangkap 4
(5) $=$ perangkap 5

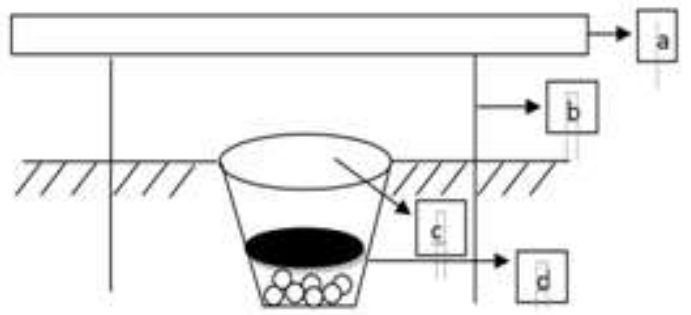

Gambar 2. Pitfalltrap

Keterangan :

a. Atap plastik Mika $(15 \mathrm{~cm} \times 20 \mathrm{~cm})$

b. Tiang bambu $25 \mathrm{~cm}$

c. Ember Plastik (diameter $13 \mathrm{~cm}$ )

d. Larutan detergen

dikoleksi dalam alkohol 70\%, kemudian di bawa ke laboratorium untuk dihitung dan diidentifikasi. Identifikasi arthropoda dilakukan sampai tingkat ordo.

\section{Analisis Data}

Variabel yang diamati meliputi kepadatan populasi relatif tiap ordo, indeks Shannon, indeks Simpson, dan nilai pentingordo arthropoda. Kepadatan populasi relatif ordo arthropoda dihitung dengan rumus sebagai berikut (Suin, 1997):

$$
\mathrm{p}_{\mathrm{i}}=\left(\mathrm{n}_{\mathrm{i}} / \mathrm{N}\right) \times 100 \%
$$

dimana, $\mathrm{p}_{\mathrm{i}}=$ kepadatan populasi relatif jenis ke- $\mathrm{i}$, $\mathrm{n}_{\mathrm{i}}=$ jumlah jenis ke- ${ }_{\mathrm{i}}$, dan $\mathrm{N}=$ jumlah total seluruh individu. Indeks Shannon dihitung dengan rumus (Agustinawati et al. 2016):

$$
\mathrm{H}=-\sum \text { pilnpi }
$$

dimana, H'= indeks keanekaragaman Shannon-Wiener, $\mathrm{p}_{\mathrm{i}}=\mathrm{n}_{\mathrm{i}} / \mathrm{N}, \mathrm{n}_{\mathrm{i}}=$ kemelimpahan jeniske- $_{\mathrm{i}}$ dan $\mathrm{N}=$ jumlah total individu dalam sampel.

Indeks Simpson dihitung dengan rumus (Agustinawati et al.2016) :

$$
\mathrm{D}=1-\sum(\mathrm{pi})^{2}
$$

dimana, $\mathrm{D}=$ indeks Simpson, $\mathrm{p}_{\mathrm{i}}=$ kepadatan relatif jenis $\mathrm{ke}_{\mathrm{i}}, \mathrm{p}_{\mathrm{i}}=\left(\mathrm{n}_{\mathrm{i}} / \mathrm{N}\right)$,

Nilai Penting untuk masing-masing jenis arthropoda dihitung dengan rumus (Elhayati et al. 2017):

$$
\mathrm{PV}=\operatorname{di} \sqrt{\mathrm{fi}}
$$

dimana, $\mathrm{PV}=$ nilai penting (prominent value), $\mathrm{d}_{\mathrm{i}}=$ kelimpahan jenis ke $-\mathrm{i}$, dan $\mathrm{f}_{\mathrm{i}}=$ frekuensi kemunculan jenis ke-i/seluruh petak perlakuan.

\section{HASIL DAN PEMBAHASAN}

Hasil pengamatan menunjukkan bahwa total individu Arthropoda permukaan tanah yang tertangkap pada lahan pertananaman ubi kayu di enam lokasi bervariasi (Tabel 2). Total individu arthropoda yang tertangkap pada pertanaman ubi kayu diDesa Pekalongan Lampung Timur mencapai 652 ekor per 6 pit fall, sementara pada lokasi desa lainnya berkisar $228-540$ individu per 6 pit fall. Total individu yang tinggi di lokasi desa Pekalongan diduga karena kondisi lingkungan pada lokasi tersebut cocok bagi komunitas arthropoda yaitu tanaman ubikayu sudah berumur tua (12 bulan) sehingga tutupan kanopinya rimbun dan ditambah hamparannya luas. Pertanaman ubi kayu di lokasi lainnya berumur 4-7 bulan. 
Tabel 2. Total individu Arthropoda permukaan tanah yang tertangkap pada pertanamanubi kayu di enam lokasi berbeda.

\begin{tabular}{clc}
\hline No. & \multicolumn{1}{c}{ Lokasi Pertanaman Ubi Kayu } & Total individu arthropoda per 6 pitfall \\
\hline 1 & Desa Tanjung Sari 1, Lampung Selatan (7 bulan) & 540 \\
2 & Desa Tanjung Sari 2, Lampung Selatan (4 bulan). & 434 \\
3 & Desa Bumi Aji 1, Lampung Tengah (5 bulan). & 265 \\
4 & Desa Bumi Aji 2, Lampung Tengah (7 bulan). & 300 \\
5 & Desa Pekalongan, Lampung Timur (12 bulan) & 652 \\
6 & Desa Sukaraja Nuban, Lampung Timur (6 bulan) & 228 \\
\hline
\end{tabular}

Tabel 3. Kepadatan populasi relatif ordo-ordo Arthropoda tanah pada pertanaman ubi kayu di enam lokasi berbeda.

\begin{tabular}{lcccccc}
\hline \multirow{1}{*}{\multicolumn{1}{c}{$\begin{array}{c}\text { Arthropoda } \\
\text { yang ditemukan }\end{array}$}} & Lj Sari1 & Tj Sari2 & BmAji1 & Bm Aji2 & Pekalongan & Sukaraja Nbn \\
\cline { 2 - 6 } & \multicolumn{7}{c}{$\ldots \ldots \ldots \ldots \ldots \ldots \ldots \ldots \ldots \% \ldots \ldots \ldots \ldots \ldots \ldots \ldots \ldots \ldots \ldots$} \\
\hline Semut (Hymenoptera) & 62,17 & 70,77 & 35,49 & 15,46 & 19,44 & 32,48 \\
Ekor pegas (Collembola) & 34,84 & 25,77 & 48,86 & 79,71 & 75,40 & 57,62 \\
Kaki seribu (Milipedes) & 0,21 & 0,50 & 3,39 & 0,37 & 0,30 & 0,32 \\
Belalang (Orthoptera) & 0 & 0,26 & 0,71 & 0,19 & 0,42 & 1,74 \\
Cengkerik (Orthoptera) & 1,21 & 0,78 & 6,07 & 2,76 & 3,05 & 2,15 \\
Laba-laba (Araneae) & 0,96 & 1,66 & 1,48 & 0 & 0,93 & 1,03 \\
Kumbang Coleoptera) & 0,61 & 0,26 & 3,99 & 1,50 & 0,47 & 4,68 \\
\hline
\end{tabular}

Ditemukan enam ordo arthropoda pada pertanaman ubikayu yang diamati (Tabel 3). Keenam kelompok arthropoda yang ditemukan meliputi kelas Insekta yang terdiri dari semut (Hymenoptera), ekor pegas (Collembola), Belalang(Orthoptera), Cengkrik (Orthoptera), kumbang (coleoptera), kelas Diplopoda yaitu kaki seribu (Milipedes), dan kelas Arachnida yaitu laba-laba (Araneae). Kelimpahan relatif ordo arthropoda antar lokasi pertanaman ubi kayu bervariasi. Namun demikian, secara umum kelimpahan relatif semut dan Collembola paling tinggi pada semua lokasi pertanaman ubi kayu yang diamati. Kelimpahan relatif semut pada pertanaman ubi kayu di Desa Tanjung Sari1 dan Tanjung Sari-2 mencapai berurutan 62,70\% dan 70,77 \%.Demikian pula Collembola, arthropoda ini kelimpahan relatifnya tinggi di Desa Bumi Aji-2 dan Pekalongan yang berurutan sebesar 79,71\% dan
$75,40 \%$. Sementara kelimpahan relatif ordo lainnya rendah pada semua lokasi pertanaman ubi kayu, yaitu 0-6 persen. Kelimpahan semut dan Collembola yang tinggi disebabkan adanya peningkatan pertumbuhan rumput, dengan lebatnya rumput memungkinkan adanya akumulasi serasah dan sumber makanan yang dapat memberikan kenyamanan habitat bagi semut dan Collembola (Erwinda et al. 2016). Collembola memiliki peranan pertama dalam proses perombakan/ penguraian sisa-sisa tanaman seperti serasah daun yang jatuh ke permukaan tanah (Susilo, 2007).

Collembola dan semut merupakan kelompok arthropoda yang banyak beraktivitas di permukaan tanah sehingga banyak tertangkap dengan pitfall trap pada penelitian ini. Muliet al.(2015) menyatakan ordo Collembola banyak ditemukan pada permukaan tanah karena memakan tumbuh-tumbuhan yang telah 
membusuk atau berperan sebagai dekomposer tanaman di tanah.

Semut dikenal sebagai serangga umum yang sering ditemui diberbagai tempat dan menyebar luas serta memiliki kebiasaan hidup bergerombol (berkoloni). Ma'arif et al. (2013) menyebutkan bahwa semut banyak ditemukan dipermukaan tanah gembur dan tidak tergenang air.

Indeks Shannon yang didapat pada enam lokasi pertanaman ubi kayu (Tabel 4) dapat dikategorikan tergolong sedang $\left(\mathrm{H}^{\prime}=0,62-1,17\right)$. Hal ini dapat dilihat berdasarkan indeks keanekaragaman Shannon-Wiener dalam Fitriana (2006), yang menyatakan keragaman dalam populasi dikatakan sedang apabila $1,0<\mathrm{H}^{\prime}<3,322$ yang berarti jenis-jenis arthropoda yang ada cukup beragam dan kondisi ekosistem cukup seimbang.

Nilai Indeks Simpson arthropoda tanah pada lahan pertanaman ubi kayu di enam lokasi yang berbeda disajikan pada Tabel 4. Nilai indeks Simpson tersebut masuk ke dalam kisaran kategori sedang. Nilai Indeks Simpson pada lokasi 1 sampai 6 menunjukkan nilai D $=0,3-0,5$. Menurut Odum (1993), nilai Indeks Simpson yang mengindekasikan tidak adanya jenis yang mendominasi apabila D (Indeks Simpson) antara $0,61-1,0$, nilai D pada kisaran $0,3-0,6$ masuk dalam kategori sedang, dan nilai D pada kisaran 0-0,3 masuk dalam kategori rendah yang berarti ada jenis yang mendominasi.

Nilai penting atau nilai prominen menunjukkan kedudukan suatu jenis terhadap jenis lain di dalam suatu komunitas. Semakin besarnilai indeks berarti jenis yang bersangkutan semakin besar berperan di dalam komunitas yang bersangkutan.

Nilai penting komunitas arthropoda yang di dapat pada setiap lokasi didominasi oleh Collembola. Collembola ini memiliki nilai PV paling tinggi terutama di desa Pekalongan, Lampung Timur yaitu sebanyak 499. Selanjutnya di desa Bumi Aji-2 yaitu $P V=245$ (Tabel 5). Collembola adalah arthropoda yang paling

Tabel 4. Nilai Indeks Shannon dan Simpson Arthropoda pada pertanaman ubi kayu di Lampung

\begin{tabular}{lcc}
\hline \multicolumn{1}{c}{ Lokasi } & H' & D \\
\hline Desa Tanjung Sari 1, Lampung Selatan & 0,79 & 0,4 \\
Desa Tanjung Sari 2 Lampung Selatan & 0,75 & 0,4 \\
Desa Bumi Aji 1, Lampung Tengah & 1,17 & 0,5 \\
Desa Bumi Aji 2, Lampung Tengah & 0,62 & 0,5 \\
Desa Pekalongan, Lampung Timur & 0,72 & 0,3 \\
Desa Sukaraja Nuban, Lampung Timur & 1,0 & 0,5 \\
\hline
\end{tabular}

Tabel 5. Nilai Penting Arthropoda (PV) pada 6 lokasi pertanaman ubi kayu di Lampung.

\begin{tabular}{lcccccc}
\hline Jenis Arthropoda & Tj Sari1 & Tj Sari2 & Bm Aji1 & Bm Aji2 & Pekalongan & Sukaraja Nbn \\
\hline Semut & 355 & 311 & 109 & 38,46037 & 123 & 77 \\
Collembola & 168 & 108 & 121 & 245 & 499 & 132 \\
Kaki Seribu & 0,447214 & 1,264911 & 8 & 0,447214 & 1,264911 & 0,447214 \\
Belalang & 0 & 0,447214 & 0,447214 & 0,447214 & 2,32379 & 0,894427 \\
Cengkerik & 5,059644 & 1,897367 & 12,52198 & 4,64758 & 15,20526 & 3,577709 \\
Laba-Laba & 3,872983 & 7,155418 & 2,32379 & 0 & 3,872983 & 1,264911 \\
Kumbang & 2,32379 & 0,447214 & 8,049845 & 2,529822 & 1,897367 & 6,324555 \\
\hline
\end{tabular}


banyak muncul di setiap lokasi pertanaman ubi kayu.Collembola berada pada permukaan tanah maupun pada lapisan tajuk pohon atau belukar bahkan tempat-tempat yang tersembunyi.Collembola dengan kelimpahannya yang cukup tinggi bukan hanya sebagai dekomposer, tetapi juga sebagai penyangga (buffer) yang dapat mempertahankan kehidupan arthropoda predator dan juga sebagai indikator tanah.

Arthropoda lain yang memiliki nilai PV tinggi adalah Semut. Semut termasuk penting dalam komunitas arthropoda karena semut memiliki habitat yang cocok sehingga mendominasi di permukaan tanah. Semut dapat menjadi indikator kesehatan lingkungan tanah. Semut juga memiliki kebiasaan memakan arthropoda lain, memakan jamur, memakan embun madu serta pertukaran makanan antar individu-individu yang lainnya. Habitat pertanaman ubi kayu cocok bagi Collembola dan semut, sehingga kedua ordo ini dominan di dalam komunitas arthropoda permukaan tanah.

\section{KESIMPULAN}

Berdasarkan hasil penelitian ini, dapat disimpulkan bahwa setiap lokasi penanaman ubi kayu di Lampung memiliki kemelimpahan dan keanekaragaman arthropoda yang bervariasi. Dari keenam lokasi (Desa Tanjung Sari 1, Tanjung Sari 2, Bumi Aji 1, Bumi Aji 2, Pekalongan, dan Sukaraja Nuban) ditemukan semut, Collembola, kaki seribu, belalang, cengkerik, laba-laba dan kumbang dengan kelimpahan yang bervariasi. Di antara enam ordo arthropoda yang ditemukan, terdapat dua ordo yang kelimpahannya tinggi dan memiliki nilai penting tinggi, yaitu Collembola dan Hymenoptera (semut). Nilai indeks Shannon $\mathrm{H}^{\prime}=0,62-1,17$ dan nilai indeks Simpson D=0,3-0,5.

\section{DAFTAR PUSTAKA}

Agustinawati, Toana, M.H., \& Wahid, A. 2016. Keanekaragaman Atrhropoda Permukaan Tanah Pada Tanaman Cabai (Capsicum annum L.) dengan Sistem Pertanian yang Berbeda di Kabupaten Sigi.e-J. Agrotekbi. 4(1) : 8-15.

Arief R. W. \&Asnawi, R. 2008. Teknologi Budidaya Ubi kayu. Balai Pengkajian Teknologi Pertanian Lampung. Bandar Lampung. $21 \mathrm{hlm}$.

Bonkowski, M., Griffiths, B.,\& Scrimgeour, C. 2000. Substrate heterogeneity and microfauna in soil organic 'hotspots' as determinants of nitrogen capture dan growth of ryegrass. Appl. Soil Ecol. 14: 37-53.

BPS. 2015. Data Produktivitas Ubi kayu Indonesia dan Provinsi Lampung. https://www.BPS.go.id. Diakses tanggal 12 januari 2017.

Elhayati, Hariri, A.M., \& Wibowo, L. 2017. Keanekaragaman Arthropoda Permukaan Tanah pada Pertanaman Ubi Kayu (Manihot utilissima Pohl.) Setelah Perlakuan Olah Tanah dan Pengelolaan Gulma. J. Agrotek Tropika. 5(3) : 158-164.

Erwinda, Widyastuti, R., Djajakirana, G., Suhardjono, Y. R. 2016. Keanekaragaman dan Fluktuasi Kelimpahan Collembola di Sekitar Tanaman Kelapa Sawit di Perkebunan Cikasungka Kabupaten Bogor. J. Entomologi Indonesia. 13 (2) : 99-106.

Fitriana, Y.R. 2006. Keanekaragaman dan Kemelimpahan Makrozoobentos di Hutan 
Mangrove Hasil Rehabilitasi Taman Hutan Raya Ngurah Rai Bali. Biodiversitas. 7(1):67-72.

Ma'arif, S., Suartini, N.M., \& Ginantara, I.K.2013. Diversitas Serangga Permukaan Tanah pada Pertanian Holtikultura Organik di Banjar Titigalar, Desa Bangli Kabupaten Tabanan Bali. Jurnal Biologi. XVIII(1):28-32.

Moore, J.C. \& Walter D.E. 1988. Arthropod Regulation of micro dan Mesobiota in below ground food webs. Annual Review of Entomology. 33: 419-439.

Muli, R., Irsan, C., \& Suheryanto.2015. Komunitas Arthropoda Tanah di Kawasan Sumur Minyak Bumi di Desa Mangun Jaya Provinsi Sumatera Selatan.Jurnal Ilmu Lingkungan. 13(1):1-11.
Odum, E.P. 1993. Dasar-Dasa Ekologi Edisi Ketiga. Penerjemah Samingan, T. Gadjah Mada University Press. Yogyakarta.

Ruslan, H. 2009. Komposisi Dan Keanekaragaman Serangga Permukaan Tanah pada Habitat Hutan Homogen Dan Heterogen di Pusat Pendidikan konservasi Alam (PPKA) Bodogol, Sukabumi, Jawa Barat. Vis Vitalis. 2(1) : 43-53.

Suin, N.M. 1997. Ekologi Hewan Tanah. Penerbit Bumi Aksara. Jakarta. 189 hlm.

Susilo, F.X. 2007. Pengendalian Hayati dengan Memberdayakan Musuh Alami Hama Tanaman. Yogyakarta: Graha Ilmu. $120 \mathrm{hlm}$. 